\title{
中国北方典型草原区花粉产量及其定量重建 古植被的作用
}

\author{
许清海 $^{(1) *}$, 曹现勇 ${ }^{(1)(2)(4) ~}$ Fang TIAN $^{(3)}$, 张生瑞 ${ }^{(1)}$, 李月丛 ${ }^{(1)}$, 李曼玥 ${ }^{(1)}$,

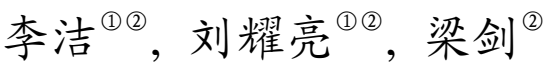 \\ (1) 河北师范大学泥河湾考古研究院, 石家庄 050024; \\ (2) 河北师范大学资源与环境科学学院, 河北省环境演变与生态建设重点实验室, 石家庄 050024; \\ (3) Alfred Wegener Institute Helmholtz Centre for Polar and Marine Research, Research Unit Potsdam, Potsdam 14473, Germany; \\ (4) Institute of Earth and Environmental Sciences, University of Potsdam, Potsdam 14476, Germany \\ *E-mail: xuqinghai@mail.hebtu.edu.cn
}

收稿日期: 2013-05-02; 接受日期: 2013-08-22; 网络版发表日期: 2013-11-26

中国科学院战略性先导科技专项(编号: XDA05120202)、国家自然科学基金项目(批准号: 41071132,41371215)、河北省科技厅科技支撑重 点项目(编号: 13277611D)、河北省环境演变与生态建设重点实验室和河北省重点学科基金资助

\begin{abstract}
摘要＼cjkstart基于中国北方典型草原区 30 个样点现代孢粉分析和植被调查，研究估算了常见花粉 类型的相对花粉产量, 并将估算结果应用于全新世以来的古植被定量重建. 典型草原区现代 花粉组合以蒿属、藜科、禾本科、莎草科和菊科等草本植物花粉为主，与草原区植物群落较 一致.中国北方典型草原区上述五种主要花粉类型和常见花粉类型(唐松草属、感尾科、委陵 菜属、麻黄属、十字花科和榆属)的风力传播能力强, 相对花粉源 $1000 \mathrm{~m}$ 左右(以表土样品取 样范围为沉积盆地半径, $0.5 \mathrm{~m})$, 且基本不受风速影响. 榆属、蒿属、十字花科和藜科植物花粉 产量最高, 唐松草属植物花粉产量较高, 而菊科和感尾科植物花粉产量较低, 禾本科、莎草 科、委陵菜属和麻黄属植物花粉产量适中. 相对花粉产量检验表明: 多数花粉类型相对花粉产 量结果可信; 但菊科和盛尾科相对花粉产量被显著低估, 禾本科、䓠科、麻黄属相对花粉产量 被高估或低估, 利用相对花粉产量定量重建古植被时应谨慎. 依据花粉产量定量重建的植被 演替表明, 现在的中国北方典型草原区6500 5600 cal. a BP 之前为以禾本科、莎草科和蒿属植 物为主的草甸草原, 之后逐渐演变为现在的典型草原.
\end{abstract}

关键词

典型草原

表土花粉

相对花粉产量

相对花粉源

古植被重建
化石花粉易于获得, 蕴含的植物群落信息也较 完整，是重建植被成分和演替过程最为理想的代用 指标. 但化石花粉组合中某一花粉类型的百分比含 量并不直接等同于该种植物在群落中的丰度(许清海 等, 2006). 例如, 中国北方草原区以禾本科草类为建
群种或优势种群落的现代花粉组合中, 禾本科花粉 含量通常低于 $10 \%$ ，而蒿属和藜科花粉往往是最主 要的花粉类型(Liu 等, 1999; 李月丛等, 2005; 许清海 等, 2007; Xu 等, 2009). 目前对化石花粉组合的解释 多处于主观经验性阶段. 利用化石花粉组合解释植

中文引用格式: 许清海, 曹现勇, Tian F, 等. 中国北方典型草原区花粉产量及其定量重建古植被的作用. 中国科学: 地球科学, 2013, 43: 2016-2028

英文引用格式: Xu Q H, Cao X Y, Tian F, et al. Relative pollen productivities of typical steppe species in northern China and their potential in past vegetation reconstruction. Science China: Earth Sciences, 2013, doi: 10.1007/s11430-013-4738-7 
被群落变化时, 研究人员往往感性地削减蒿属和藜 科植物的丰度, 提高禾本科植物的丰度, 却不能给出 定量结果(Xiao 等, 2004; Cao 等, 2010); 甚至只关注 蒿属和藜科花粉含量的变化, 而忽略其他草本植物 花粉含量的变化(羊向东等, 1995). 为了减小解释古 植被成分时因不同花粉类型对植被代表性差异引起 的偏差, 弄清不同植物类型的花粉产量是古植被定 量重建的有效途径.

由于植物的花粉生产能力很难估算, Andersen 于 1970 年提出了相对花粉产量的概念(Andersen, 1970): 以植物群落和花粉组合中出现频率较高的某一类型 的花粉生产能力为参考值(相对花粉产量为 1 ), 将其 他类型花粉生产能力与之对比, 得到的比值即为相 对花粉产量, 用于衡量不同植物类型花粉生产能力 的差异. 相对花粉产量估算研究在欧洲广泛开展. 研 究人员已构建出一系列涵盖植被数据整理(HUMPOL 软件(Bunting 等, 2005b))、花粉产量估算(ERV 模型 (Parsons 等, 1981; Sugita, 1994)) 和植被定量重建 (REVEALS 和 LOVE 模型(Sugita, 2007a, 2007b))的模 型, 并估算出不同地区主要植物类型以禾本科植物 花粉产量为参照的相对花粉产量(Soepboer 等, 2007; Bunting 等, 2005a; Broström 等, 2004; Räsänen 等, 2007). 已有的研究表明: (1) 由于气候、土壤、环境、 植物生长状态等因素的差异, 不同地区同一植物的 相对花粉产量存在显著差异(Hicks，2001; Schofield 等, 2007; Hättestrand 等, 2008); (2) 相对花粉产量的 差异对植被定量重建影响显著(Sugita，2007a，2007b; Broström 等, 2008). 总之, 某一地区的相对花粉产量 不能直接应用到另一地区. 中国已开展了一些相对 花粉产量的估算工作, 如 $\mathrm{Li}$ 等(2011)利用上述模型估 算了鄂尔多斯高原和阿拉善高原荒漠和半荒漠地区 蒿属、藜科、禾本科和白刺属的相对花粉产量; Wang 等(2011)研究了青藏高原东部蒿属、藜科、禾本科和 莎草科的相对花粉产量, 并将其应用于古植被重建. 以上两篇报道成功地将相对花粉产量估算和应用模 型应用到中国, 但植被调查数据精度低, 影响了估算 结果的可靠性. 中国不同气候区、不同植被类型主要 植物类型相对花粉产量估算工作尚待开展.

中国北方典型草原区位于东亚季风尾问区，植 被对全新世以来气候变化响应敏感(Wang 等, 2001; Jiang 等, 2006). 同时该地区也是历史时期人类活动 的重要场所(任国玉, 1999), 研究该地区主要植物类
型相对花粉产量及基于其定量重建全新世以来的古 植被变化, 可以揭示该地区植被对气候变化和人类 活动的响应机制, 对现代草原植被保护及恢复具有 重要的指导意义. 本研究在锡林格勒温带草原自然 保护区和浑善达克沙地选取表层土壤样品做孢粉分 析, 结合详细的植被调查数据, 估算了中国北方典型 草原区主要植物类型(蒿属、藜科、禾本科、莎草科、 菊科、委陵菜属、唐松草属、萭尾科、十字花科、榆 属和麻黄属)的相对花粉产量, 并选取研究区域内高 质量的化石花粉记录(Wang 等, 2001; Jiang 等, 2006), 定量重建了该地区全新世以来植被群落成分的演替 过程.

\section{1 研究区域}

研究区域主要包括锡林格勒温带草原自然保护 区和浑善达克沙地东部, 位于内蒙古自治区锡林郭 勒盟中部. 该区域位于温带大陆性季风气候尾问区, 属温带半干早气候. 冬季受蒙古高压气团控制, 寒冷 干燥; 夏季受东亚夏季风影响, 较温暖湿润. 多年平 均气温为 $0 \sim 1{ }^{\circ} \mathrm{C}$. 年降雨量在 300 450 $\mathrm{mm}$ 之间, 多 集中在夏秋季节 (7, 8, 9 月份). 而年蒸发量在 1600 2200 mm 之间. 平均风速 $3.5 \mathrm{~m} \mathrm{~s}^{-1}$, 极大风速 $29 \mathrm{~m} \mathrm{~s}^{-1}$. 地势较平坦, 海拔在 800 1400 m 之间. 地 带性土壤为栗钲土, 研究区西部的浑善达克沙地以 风沙土为主(牛建明, 2000; 王永利等, 2007; 李素英 等, 2007).

锡林格勒温带草原自然保护区植被是以大针茅 (Stipa grandis)、羊草(Leymus chinensis)、冰草 (Agropyron cristatum) 等禾本科(Poaceae)植物为建群 种的典型草原, 群落内常见植物还包括蒿属 (Artemisia)、菊科(Asteraceae)、藜科(Chenopodiaceae)、 莎草科(Cyperaceae)等. 在地下水条件较好的区域, 分布有以禾本科和莎草科植物为主的湿生或盐渍化 草甸(王永利等, 2007; 李素英等, 2007). 浑善达克沙 地是典型的草本、灌木、乔木共生体系. 固定和半固 定沙丘和丘间低地主要分布以羊草、冰草等禾草以及 蒿属为主的群落; 流动沙丘分布有以沙蓬(Agriophyllum sqnarrosum)、虫实(Corispermum sp.)等为主的先 锋群落. 落叶灌丛群落所在生境大多地势平缓、土质 肥沃、地下水充足, 常见的灌木种是小红柳(Salix microstachya). 其间夹杂柴桦(Betula fruticosa), 草本 


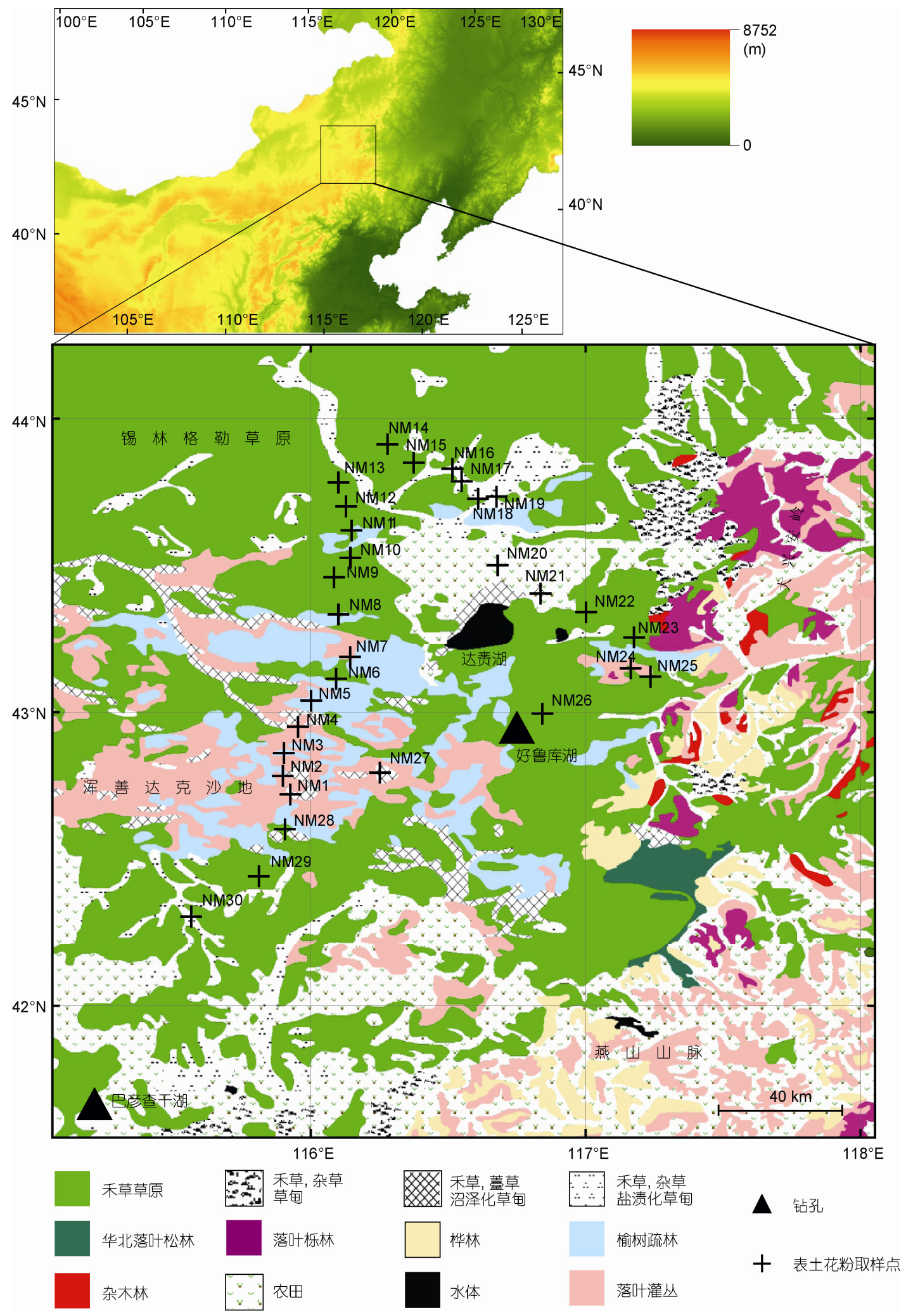

图 1 研究区地理位置及主要植被类型(侯学显, 2001) 
层以湿生性的芦苇(Phragmites communis) 和苔草 (Carex)为主. 散生乔木以榆(Ulmus pumila) 为优势种, 形成榆树疏林, 林下缺少灌木层(李刚, 2006). 研究 区东部和南部低山丘陵区分布有以华属(Betula)、栋 属(Quercus)、落叶松属(Larix)、松属(Pinus) 和杨属 (Populus)等为主的林地. 研究区内零散分布(集中在 南部地区)有以小麦(Triticum)、玉米(Zea) 等为主要作 物的农田(图 1).

\section{2 材料与方法}

\section{1 样品采集和植被调查}

2011 年 8 月, 在研究区域内随机选取 30 个样点 开展表层土壤样品采集和植被调查(图 1). 为了减小 人类活动对植物生长状态的影响, 样点尽可能选取 代表性较强, 分布面积较大, 人类活动影响较小的植 物群落. 样点间距大于 $3 \mathrm{~km}$, 以防出现共线性影响. 采用全球定位系统(GPS) 记录样点地理坐标. 在每个 样点周围 $0.5 \mathrm{~m}$ 半径范围内采用梅花式布点采集表土 样品, 主要采集地表的枯枝落叶物和苔藓, 没有枯枝 落叶物和苔藓的样点, 采集 $0 \sim 1 \mathrm{~cm}$ 的表土. 植被调 查方法采用同心圆法(Broström 等, 2004). 如图 2 所示, 沿东、南、西、北四个方向分别记录距样点中心 1.5 , $3,6,10 \mathrm{~m}$ 圆环内植被信息, 并沿东北、东南、西南、

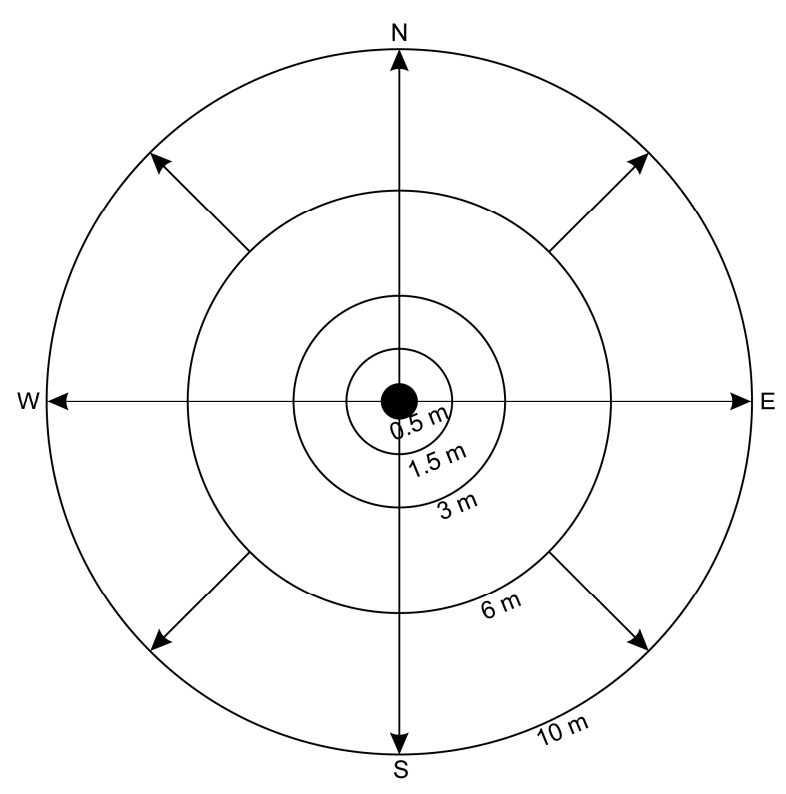

图 2 植被调查同心圆法
西北四个方向随机调查 10 100 m 范围内的植被状况， 目视观察 100 1000 m 范围内的植被变化. 植被调查 记录裸地盖度、群落成分及各种成分投影盖度. 样点 详细信息见表 1 .

\section{2 实验室处理}

花粉分析实验室取样干重 $20 \mathrm{~g}$. 花粉提取采用 常规的酸、碱处理(Faegri 等, 1989)结合重液浮选法 (重液比重 1.9). 样品处理前加入一粒石松孢子片 (27637 粒/片)作为示踪剂. 每个样品鉴定统计花粉 1000 粒以上. 花粉鉴定同时, 测量 100 粒常见花粉类 型的长轴直径和短轴直径, 其中球型花粉(蒿属、愁 科、禾本科、菊科、委陵菜属、唐松草属、十字花科 和榆属)采用 Stoke 法, 而椭球型花粉(莎草科、鸢尾 科和麻黄属)采用 Falck 法计算花粉沉降速率(Gregory, 1973).

\section{3 数据处理}

距样点不同距离的植被盖度数据计算采用 HUMPOL 软件包内的一系列软件完成(Bunting 等, 2005 b), 并将植被丰度整理成 30 个独立的 CSV 文件. $100 \mathrm{~m}$ 外的植被数据来自数字化的中国植被图(分辨 率为 $1: 100$ 万)(侯学爆, 2001). 计算了距采样点 6000 $\mathrm{m}$ 范围内的植被数据, 并结合目视调查结果校正 100 6000 m 范围的数据化植被数据. 使用 ERV Analysis v1.2.3 软件(Shinya Sugita, 未发表)计算相 对花粉产量. ERV 模型包含三个子模型, 子模型之间 的区别在于背景花粉的定义(Parsons 等, 1981; Sugita, 1994): 子模型 1 假设每个花粉类型的背景花粉百分 比不变; 子模型 2 假设植被调查范围内总植被丰度条 件下每个花粉类型的背景花粉沉降量不变; 而子模 型 3 假设每个花粉类型的背景花粉沉降量是固定的. 子模型 1 和 2 要求植被丰度为百分比数据(如投影盖 度等), 而子模型 3 需要绝对植被丰度数据(如立木材 积量等). 本研究中植被调查和表土花粉数据均为百 分比数据, 为此, 只采用了子模型 1 和 2 , 分别结合 四种距离加权法 ( $1 / d, 1 / d^{2}$, Prentice 模型和 Sugita 模型) 估算相对花粉源和相对花粉产量 (以禾本科为参考 种), 利用所得到的似然函数得分值选择最合理的子 模型和距离加权法. 模型运算时输入包含每个样点 花粉统计数据的 CSV 文件、花粉沉降速率的 CSV 文 件和包含 30 个样点植被数据文件名的 CSV 文件(所 
表 1 采样点地理位置及植被信息表

\begin{tabular}{|c|c|c|c|c|c|}
\hline $\begin{array}{l}\text { 样点 } \\
\text { 编号 }\end{array}$ & $\begin{array}{l}\text { 纬度 } \\
(\mathrm{N})\end{array}$ & $\begin{array}{l}\text { 经度 } \\
(\mathrm{E})\end{array}$ & $\begin{array}{l}\text { 海拔 } \\
(\mathrm{m} \text { a.s.l) }\end{array}$ & 群落类型 & 主要植物类型 \\
\hline NM1 & $42.7194^{\circ}$ & $115.9304^{\circ}$ & 1319 & 沙柳+杂草类群落 & $\begin{array}{c}\text { 沙柳、蒿属、菉科、菊科、禾本科、荗尾科、豆科、 } \\
\text { 萎陵菜属、莎草科、十字花科等 }\end{array}$ \\
\hline NM2 & $42.7848^{\circ}$ & $115.9007^{\circ}$ & 1313 & 蒿属+大针茅草+旱芦苇群落 & $\begin{array}{l}\text { 蒿属、禾本科、藜科、菊科、岕尾科、豆科、萎陵菜 } \\
\text { 属、莎草科、十字花科、百合科、唐松草等 }\end{array}$ \\
\hline NM3 & $42.8586^{\circ}$ & $115.9011^{\circ}$ & 1308 & 蒿属+菊科+榆树疏林群落 & $\begin{array}{c}\text { 蒿属、菊科、榆树、盡尾科、豆科、藜科、萎陵菜属、 } \\
\text { 莎草科等 }\end{array}$ \\
\hline NM4 & $42.9557^{\circ}$ & $115.9514^{\circ}$ & 1298 & 蒿属+羊草+氙尾群落 & $\begin{array}{c}\text { 蒿属、禾本科、荗尾科、黎科、莎草科、十字花科、 } \\
\text { 干枝梅、中华卷柏等 }\end{array}$ \\
\hline NM5 & $43.0424^{\circ}$ & $116.0059^{\circ}$ & 1295 & 冷蒿+莎草群落 & $\begin{array}{c}\text { 蒿属、莎草科、十字花科、藜科、禾本科、豆科、萎 } \\
\text { 陵菜属、百合科、唐松草等 }\end{array}$ \\
\hline NM6 & $43.1184^{\circ}$ & $116.0995^{\circ}$ & 1305 & 羊草+针茅草+莎草群落 & $\begin{array}{c}\text { 禾本科、莎草科、萎陵菜属、蒿属、藜科、菊科、十 } \\
\text { 字花科、陇牛儿苗科等 }\end{array}$ \\
\hline NM7 & $43.1937^{\circ}$ & $116.1382^{\circ}$ & 1300 & 蒿属+莎草群落 & 蒿属、莎草科、藜科、菊科、禾本科等 \\
\hline NM8 & $43.3364^{\circ}$ & $116.1060^{\circ}$ & 1366 & 大针茅草+冰草群落 & $\begin{array}{c}\text { 禾本科、䓤科、菊科、禾本科、豆科、萎陵菜属、莎 } \\
\text { 草科、百合科、沙葱、中华卷柏等 }\end{array}$ \\
\hline NM9 & $43.4636^{\circ}$ & $116.0853^{\circ}$ & 1422 & 大针茅草+冰草群落 & $\begin{array}{c}\text { 禾本科、锦鸡儿、蒿属、菉科、菊科、萎陵菜属、莎 } \\
\text { 草科、十字花科、百合科、唐松草等 }\end{array}$ \\
\hline NM10 & $43.5245^{\circ}$ & $116.1442^{\circ}$ & 1369 & 大针茅草+蒿属+羊草群落 & $\begin{array}{c}\text { 禾本科、蒿属、藜科、菊科、锦鸡儿、萎陵菜属、十 } \\
\text { 花科、沙䓤等 }\end{array}$ \\
\hline NM11 & $43.6261^{\circ}$ & $116.1562^{\circ}$ & 1369 & 蒿属+沙葱+大针茅草群落 & 蒿属、沙葱、禾本科、萎陵菜属、菊科等 \\
\hline NM12 & $43.705^{\circ}$ & $116.1261^{\circ}$ & 1085 & 大针茅草群落 & 禾本科、蒿属、藜科、豆科、旋花科等 \\
\hline NM13 & $43.7792^{\circ}$ & $116.1086^{\circ}$ & 1070 & 大针茅草+蒿+羊草群落 & 禾本科、蒿属、藜科、鸢尾科、锦鸡儿、沙忽等 \\
\hline NM14 & $43.9191^{\circ}$ & $116.2855^{\circ}$ & 1212 & 大针茅草+锦鸡儿+藜科群落 & 禾本科、锦鸡儿、蒿属、藜科、萎陵菜属、莎草科等 \\
\hline NM15 & $43.8563^{\circ}$ & $116.3782^{\circ}$ & 1153 & 大针茅草+蒿+羊草群落 & 禾本科、蒿属、藜科、锦鸡儿、萎陵菜属、莎草科等 \\
\hline NM16 & $43.8329^{\circ}$ & $116.5116^{\circ}$ & 1107 & 星星草+芨芨草+藜科群落 & 藜科、禾本科、蒿属、萎陵菜属、莎草科等 \\
\hline NM17 & $43.7929^{\circ}$ & $116.5493^{\circ}$ & 1146 & 大针茅草+羊草+芨芨草群落 & $\begin{array}{c}\text { 禾本科、萎陵菜属、蒿属、藜科、菊科、莎草科、唐 } \\
\text { 松草等 }\end{array}$ \\
\hline NM18 & $43.7248^{\circ}$ & $116.6149^{\circ}$ & 1236 & 大针茅草群落 & 禾本科、锦鸡儿、莎草科、沙葱等 \\
\hline NM19 & $43.7343^{\circ}$ & $116.6736^{\circ}$ & 1192 & 冷蒿+沙葱+大针茅草群落 & $\begin{array}{c}\text { 蒿属、沙葱、禾本科、藜科、菊科、萎陵菜属、莎草 } \\
\text { 科、豆科等 }\end{array}$ \\
\hline NM20 & $43.5046^{\circ}$ & $116.6863^{\circ}$ & 1327 & 冷蒿+大针茅草+沙葱群落 & $\begin{array}{c}\text { 蒿属、禾本科、沙葱、茑尾科、菊科、萎陵菜属、莎 } \\
\text { 草科、唐松草、狼毒属、伞形科等 }\end{array}$ \\
\hline NM21 & $43.4248^{\circ}$ & $116.7943^{\circ}$ & 1245 & 羊草+隐子草群落 & 禾本科、蒿属、藜科、菊科、萎陵菜属、莎草科等 \\
\hline NM22 & $43.3395^{\circ}$ & $117.0104^{\circ}$ & 1265 & 大针茅草+冷蒿群落 & $\begin{array}{c}\text { 蒿属、禾本科、藜科、菊科、萎陵菜属、莎草科、十 } \\
\text { 花科、唐松草等 }\end{array}$ \\
\hline NM23 & $43.2531^{\circ}$ & $117.175^{\circ}$ & 1288 & 冷蒿+萎陵菜群落 & $\begin{array}{c}\text { 蒿属、萎陵菜属、菉科、菊科、禾本科、莎草科、百 } \\
\text { 里香等 }\end{array}$ \\
\hline NM24 & $43.1489^{\circ}$ & $117.1721^{\circ}$ & 1303 & 叉分蓼+隐子草群落 & $\begin{array}{c}\text { 菶科、禾本科、蒿属、藜科、菊科、萎陵菜属、莎草 } \\
\text { 科、沙葱、豆科等 }\end{array}$ \\
\hline NM25 & $43.1258^{\circ}$ & $117.2353^{\circ}$ & 1210 & 蕵+隐子草+十字花科群落 & $\begin{array}{c}\text { 十字花科、蓼科、禾本科、蒿属、藜科、菊科、萎陵 } \\
\text { 菜属、莎草科、伞形科等 }\end{array}$ \\
\hline NM26 & $42.9919^{\circ}$ & $116.8482^{\circ}$ & 1327 & 冷蒿+隐子草群落 & $\begin{array}{c}\text { 蒿属、禾本科、藜科、菊科、萎陵菜属、莎草科、十 } \\
\text { 字花科、拢牛儿苗科、毛莨科、唐松草等 }\end{array}$ \\
\hline NM27 & $42.7903^{\circ}$ & $116.2491^{\circ}$ & 1345 & 羊草+蒿属+菊科群落 & $\begin{array}{c}\text { 禾本科、蒿属、藜科、十字花科、菊科、莎草科、石 } \\
\text { 竹科、毛茛科、地榆属、金形科、豆科等 }\end{array}$ \\
\hline NM28 & $42.5986^{\circ}$ & $115.9125^{\circ}$ & 1302 & 羊草+车前草群落 & $\begin{array}{l}\text { 车前草、菊科、禾本科、珟尾科、莎草科、十字花科 } \\
\text { 等 }\end{array}$ \\
\hline NM29 & $42.4333^{\circ}$ & $115.8181^{\circ}$ & 1344 & 冷蒿+萎陵菜+羊草群落 & 蒿属、萎陵菜属、禾本科、莎草科、藜科、菊科等 \\
\hline NM30 & $42.3039^{\circ}$ & $115.5666^{\circ}$ & 1300 & 冷蒿+羊草群落 & $\begin{array}{c}\text { 蒿属、禾本科、藜科、菊科、茑尾科、锦鸡儿、萎陵 } \\
\text { 菜属、莎草科等 }\end{array}$ \\
\hline
\end{tabular}


有 CSV 文件需存放在同一文件夹), 沉积盆地半径为 $0.5 \mathrm{~m}$ (表土样品取样范围), 风速设为 $3.5 \mathrm{~m} \mathrm{~s}^{-1}$ (该地 区平均风速). 为了检验花粉产量的可靠性, 我们利 用所估算的相对花粉产量和 30 个表土样品的花粉统 计数据, 使用 REVEALS 模型(Sugita, 2007a)(沉积盆 地半径设为 $0.5 \mathrm{~m}$ ) 模拟了 30 个样点的植被丰度, 并 与利用 Sugita 距离加权模型计算所得的实际植被丰 度进行了对比. 模拟植被丰度越接近于实际植被丰 度, 花粉产量结果越可信, 否则花粉产量被高估或低 估, 利用其定量重建古植被时应引起注意.

我们利用 REVEALS 模型(Sugita, 2007a) 定量重 建了研究区域内好鲁库湖和巴彦查干湖全新世以来 主要植物类型相对丰度的变化过程. 好鲁库湖位于 表土样品研究区内 $\left(42^{\circ} 57.38^{\prime} \mathrm{N}, 116^{\circ} 45.42^{\prime} \mathrm{E}\right.$, 海拔 1295 m), 巴彦查干湖位于研究区西南约 190 $\mathrm{km}\left(41^{\circ} 39^{\prime} \mathrm{N}, 115^{\circ} 12.6^{\prime} \mathrm{E}\right.$, 海拔 $\left.1355 \mathrm{~m}\right)$.

\section{3 结果}

\section{1 花粉组合特征}

30 个孢粉样品共鉴定统计出 40931 粒狍粉 (平均
每个样品鉴定 1364 粒), 包括 9 类乔木植物花粉, 8 类 灌木植物花粉, 36 类草本植物花粉和 3 类茨类植物孢 子. 草本植物花粉在花粉组合中比重最高, 主要包括 蒿属 $(5 \%$ 79\%, 中位数为 $41 \%)$ 、苝科 $(7 \%$ 67\%, 中位 数为 $30 \%)$ 、禾本科 $(0 \sim 25 \%$, 中位数为 $7 \%)$ 、莎草科 $(0 \sim 6 \%$, 中位数为 $1 \%)$ 和菊科 $(0 \sim 4 \%$, 中位数为 $1 \%)$, 忽尾科(Iridaceae, $0 \sim 6.5 \%$, 中位数为 $0.5 \%$ )、委陵菜属 (Potentilla, 0 4.1\%, 中位数为 $0.3 \%$ ) 和唐松草属 (Thalictrum, $0 \sim 1.3 \%$, 中位数为 $0.1 \%$ ) 等植物花粉较 常见; 其次是乔木植物花粉, 主要包括松属(Pinus, $0 \sim 14 \%$, 中位数为 $3 \%)$ 、桦属 $(0 \sim 5 \%$, 中位数为 $2 \%)$ 和榆属 $(0 \sim 5 \%$, 中位数为 $2 \%)$; 灌木植物花粉以麻黄 属(Ephedra, 0 4\%, 中位数为 0 ) 为主; 颜类孢子只有 少量样品出现(图 3).

我们选取了在狍粉组合和植被数据中出现频率 和含量均较高的蒿属、僽科、禾本科、莎草科、菊科、 委陵菜属、炰尾科、唐松草属、十字花科、榆属和麻 黄属花粉开展花粉沉降速率计算和相对花粉产量估算.

\section{2 花粉沉降速率}

通过测量上述 11 类花粉类型, 100 个花粉粒长轴

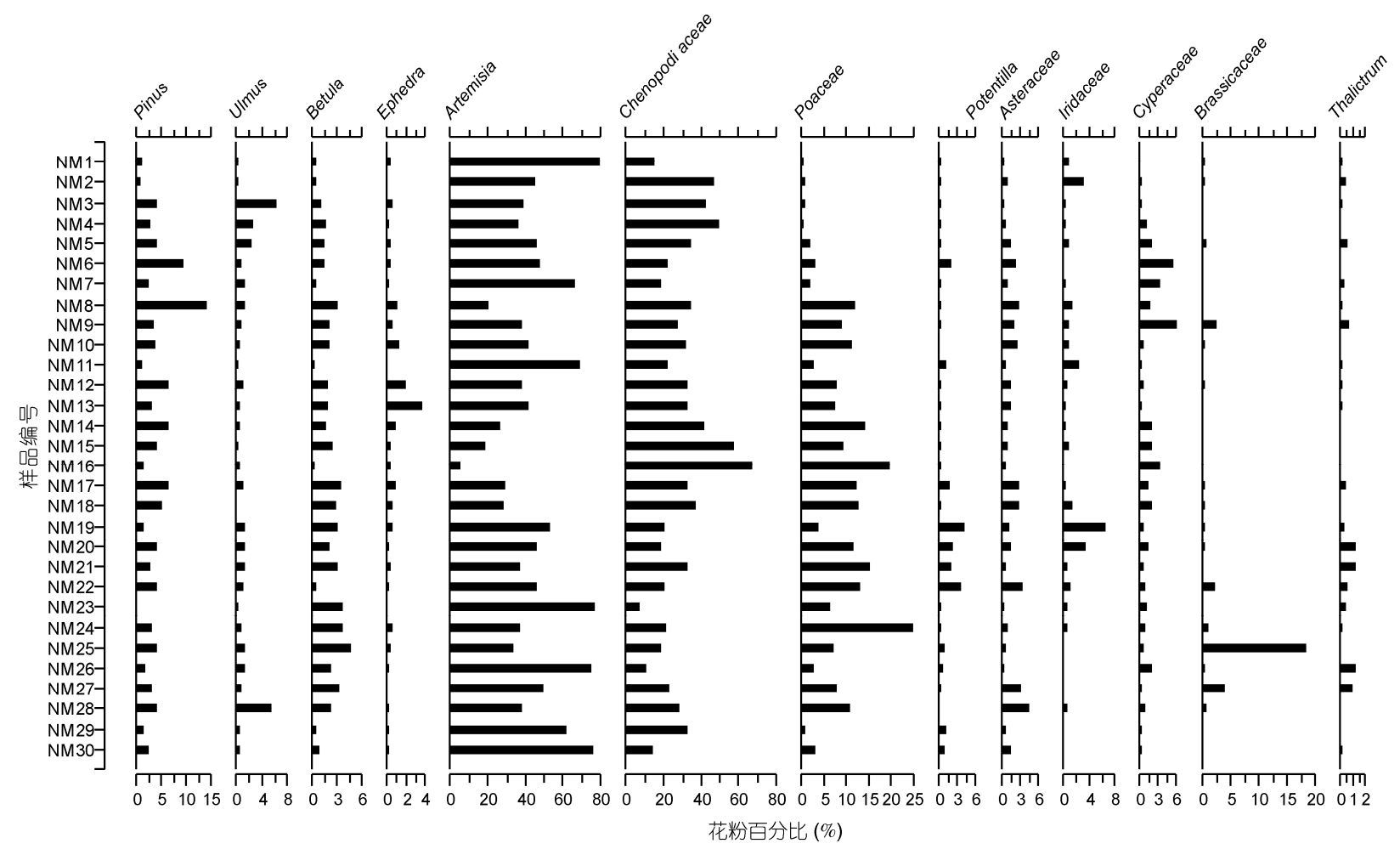

图 3 表土样品花粉组合特征图示 
和短轴的平均直径, 利用 Gregory于 1973 年提出的方 法计算出了花粉沉降速率(Gregory, 1973). 禾本科花 粉沉降速率最大, 为 $0.016 \mathrm{~m} \mathrm{~s}^{-1}$, 其次为莎草科 $\left(0.0152 \mathrm{~m} \mathrm{~s}^{-1}\right)$ 、麻黄属 $\left(0.0151 \mathrm{~m} \mathrm{~s}^{-1}\right)$ 、鸢尾科 $(0.0121$ $\left.\mathrm{m} \mathrm{s}^{-1}\right)$ 、菊科 $\left(0.0118 \mathrm{~m} \mathrm{~s}^{-1}\right)$ 、藥科 $\left(0.0108 \mathrm{~m} \mathrm{~s}^{-1}\right)$, 榆属 $\left(0.0095 \mathrm{~m} \mathrm{~s}^{-1}\right)$ 、蒿属 $\left(0.0093 \mathrm{~m} \mathrm{~s}^{-1}\right)$ 、唐松草属 $(0.0066$ $\mathrm{m} \mathrm{s}^{-1}$ ) 和委陵菜属 $\left(0.0066 \mathrm{~m} \mathrm{~s}^{-1}\right)$, 十字花科(Brassicaceae)最低, 为 $0.0034 \mathrm{~m} \mathrm{~s}^{-1}$. 总体上说, 上述 11 种 花粉沉降速率均较低, 属轻花粉(Sugita, 1993).

\section{3 花粉产量估算}

图 4 显示四种距离加权法和两个子模型两两结 合的似然函数得分值, 随离采样点距离增加的变化 趋势一致. 子模型 1 分别与 $1 / d$ 和 $1 / d^{2}$ 加权方法组合 的似然函数得分最高, 且变化趋势一致; 子模型 2 与 $1 / d$ 和 $1 / d^{2}$ 加权方法组合的似然函数得分较子模型 1 略低, 变化趋势也较一致; $1 / d$ 法和 $1 / d^{2}$ 法与两个子模 型所得到的似然函数得分均在距采样点约 $50 \mathrm{~m}$ 处显 著升高, 而后变化趋于平缓. Prentice 模型和 Sugita 模
型的似然函数得分值明显低于 $1 / d$ 和 $1 / d^{2}$ 加权法的得 分值，与子模型 2 结合所得的得分值最低，表明利用 子模型 2 估算的相对花粉产量更可信; 随离取样点距 离的增加, 得分值变化趋势均在约 $1000 \mathrm{~m}$ 处趋于平 缓, 接近于渐近线. 此外, 为检验风速对花粉源的影 响，重新运行模型并将风速设为锡林浩特地区极大 风速 $\left(29 \mathrm{~m} \mathrm{~s}^{-1}\right)$, 所得到的似然函数得分值, 随离采样 点距离增加的变化趋势与风速为 $3.5 \mathrm{~m} \mathrm{~s}^{-1}$ 时相似, 也 在 $1000 \mathrm{~m}$ 处接近于渐近线. 因此, 本研究表土样品 相对花粉源应为 $1000 \mathrm{~m}$.

分别采用 Prentice 模型和 Sugita 模型进行植被数 据距离加权, 子模型 2 估算相对花粉源为 $1000 \mathrm{~m}$ 的 相对花粉产量较一致(图 5). 本研究采用禾本科作为 参考种. 结果表明榆属 (分别为 $12.41 \pm 1.14$ 和 $11.53 \pm 1.09)$ 和蒿属 $(11.05 \pm 0.26$ 和 $11.21 \pm 0.31)$ 相对花 粉产量最高, 十字花科 $(7.56 \pm 0.34$ 和 $7.48 \pm 0.33)$ 和藥 科(5.95 \pm 0.78 和 $6.74 \pm 0.79)$ 次之, 唐松草属花粉产量 高于禾本科 $(2.83 \pm 0.40$ 和 $3.06 \pm 0.42)$, 委陵菜属 $(1.12 \pm$ 0.15 和 $1.35 \pm 0.15)$ 、麻黄属 $(1.25 \pm 0.18$ 和 $0.96 \pm 0.14)$ 、
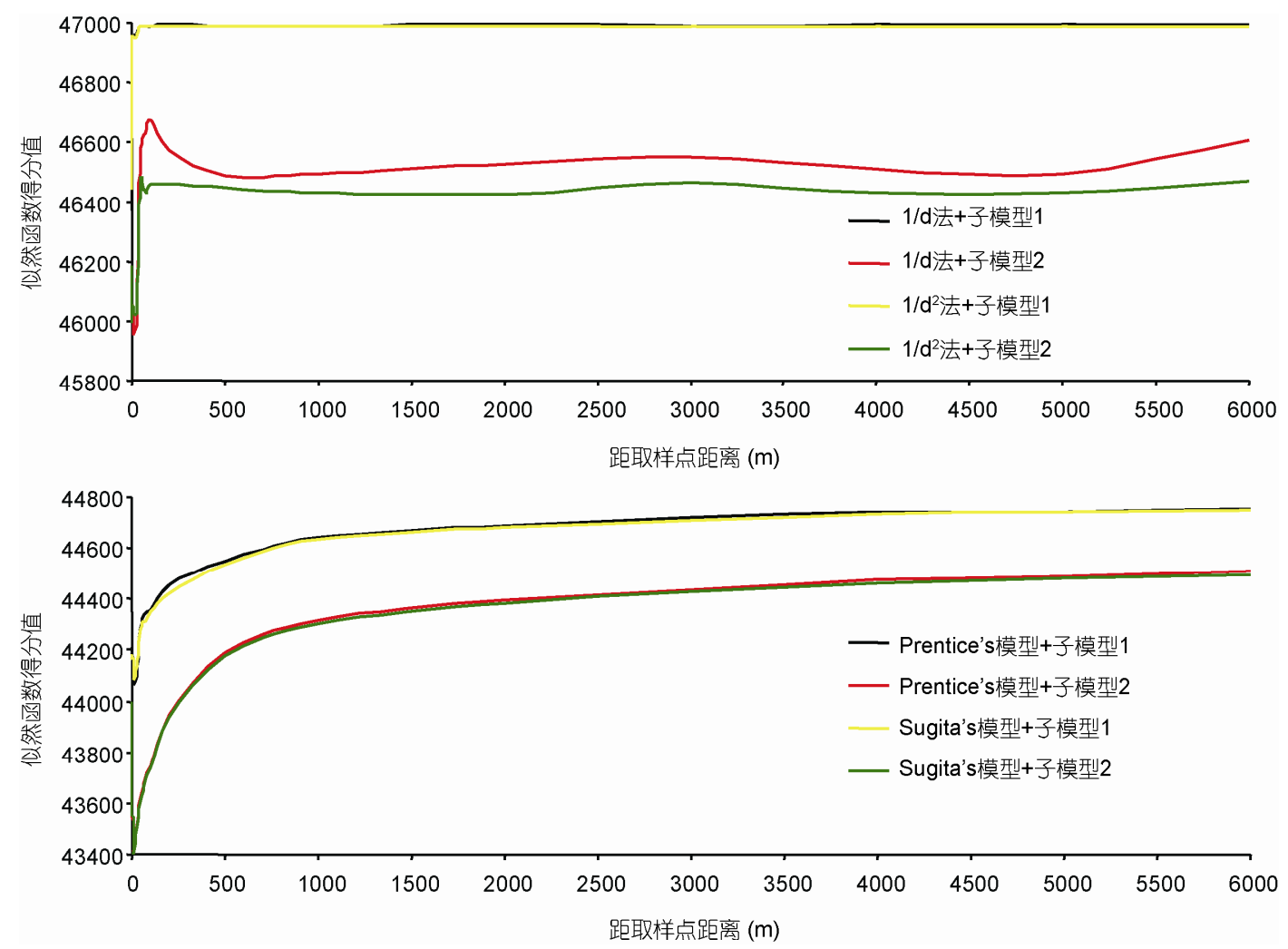

图 4 不同距离加权法和子模型组合所得似然函数得分值随离取样点距离变化的曲线 


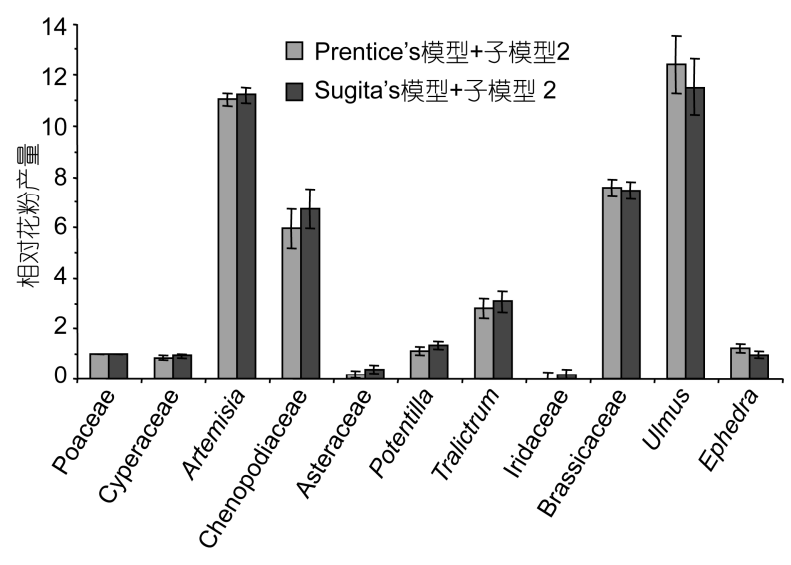

图 511 个花粉类型相对花粉产量估算结果

莎草科 $(0.86 \pm 0.08$ 和 $0.94 \pm 0.08)$ 花粉产量与禾本科相 近, 而茑尾科 $(0.009 \pm 0.25$ 和 $0.16 \pm 0.25)$ 和菊科 $(0.18 \pm$ 0.15 和 $0.39 \pm 0.16)$ 相对花粉产量明显低于禾木科.

\section{4 花粉产量检验}

我们利用子模型 2 结合 Sugita距离加权模型所估 算的相对花粉产量和 30 个表土样品的花粉统计数据, 使用 REVEALS 模型(Sugita, 2007a) 模拟了 30 个样点 的植被丰度, 并与实际植被丰度进行了对比. 检验结 果(图 6)表明: 蒿属、莎草科、唐松草属、委陵菜属、 十字花科和榆属模拟的植被丰度与实际植被丰度具 有较高的一致性, 相对花粉产量结果可信; 禾本科模 拟的植被丰度低于实际植被丰度约 $20 \%$ 40\%, 相对 花粉产量结果被高估; 愁科和麻黄属模拟的植被丰 度偏高, 表明相对花粉产量被低估; 而菊科和感尾科 (尤其是后者) 模拟的植被丰度显著高于实际植被丰 度, 其相对花粉产量被显著低估.

\section{5 植被定量重建}

好鲁库湖和巴彦查干湖全新世狍粉谱(Wang 等, 2001; Jiang 等, 2006)中都有一定量的松属和桦属花粉 (特别是在中全新世), 利用 REVEALS 模型定量重建 古植被丰度变化需要松属和桦属的相对花粉产量. 而本研究植被调查数据中没有松属和桦属植物记录, 无法估算松属和桦属的相对花粉产量. 为此, 我们不 得不借鉴欧洲松属和桦属相对花粉产量的研究结果 (松属相对花粉产量在 1.35 21.58 之间, 桦属相对花 粉产量在 2.24 8.90 之间)(Broström 等, 2008), 同时中 国北方现代花粉与植被关系研究也表明松属和桦属
花粉对植被具有超代表性(许清海等, 2007), 应具有 较高的花粉产量, 为此, 定量重建时我们将松属和桦 属花粉的相对花粉产量分别定为 6 和 8 . 我们利用子 模型 2 结合 Sugita 距离加权模型所估算的相对花粉源 为 $1000 \mathrm{~m}$ 的相对花粉产量以及借鉴的松属和桦属的 相对花粉产量定量重建了好鲁库湖和巴彦查干湖全 新世以来禾本科、莎草科、蒿属、藜科、菊科、唐松 草属、十字花科、榆属、麻黄属、松属和华属相对丰 度的变化过程. 以上 11 个花粉类型占到化石花粉组 合的 $90 \%$ 95\%, 定量重建的植被盖度可以较好地反 映好鲁库湖和巴彦查干湖区全新世以来植被景观的 变化.

好鲁库湖和巴彦查干湖的原始狍粉谱中, 全新 世以来始终以草本植物花粉蒿属和藜科为主, 禾本 科、莎草科、菊科和唐松草属等花粉含量相对较低 (Wang 等, 2001; Jiang 等, 2006), 显然与以禾本科为 主的草原植被不符. 依据相对花粉产量定量重建的 植被变化, 由于高属和藜科植物的相对花粉产量较 高, 植被丰度较花粉含量显著降低, 而禾本科、莎草 科和菊科植物花粉产量较低, 丰度明显升高, 较客观 地表现了当地区全新世以来草原植被的变化过程(图 7).

孢粉组合显示好鲁库湖地区 $5600 \mathrm{cal}$. a BP 之前 是以桦属植物为主要乔木类型的森林草原或灌丛草 原植被, 之后环境恶化演变成草原植被, 仅在 4500 3000 cal. a BP 时段有所改善(Wang 等, 2001). 依据花粉产量定量重建全新世以来好鲁库湖地区的 植被变化表明, $5600 \mathrm{cal}$. a BP 之前, 好鲁库湖地区是 以禾本科、莎草科、蒿属植物为主的草甸草原, 并伴 生桦树灌从或疏林; 之后气候变干, 环境恶化, 演变 成现在的典型草原景观, $1500 \mathrm{cal}$. a BP 之后, 藜科植 物增多.

孢粉组合显示巴彦查干湖地区全新世以来一直 是草原植被景观, 只是在 9200 6700 cal. a BP 可能出 现过林地, 10500 6500 cal. a BP 是气候最湿润时期, 当时的年均降水可能比现在多 30\% 60\%, $1500 \mathrm{cal} . \mathrm{a}$ BP 以后开始变干(Jiang 等, 2006). 花粉产量定量重建 的全新世以来巴彦查干湖地区的植被变化表明, 6500 cal. a BP 之前巴彦查干湖地区也是以禾本科、莎草 科、蒿属植物为主的草甸草原, 之后由于气候变干, 演变成典型草原, 比好鲁库湖地区早约 $900 \mathrm{a}, 2500$ cal. a BP 之后, 藜科植物显著增多. 

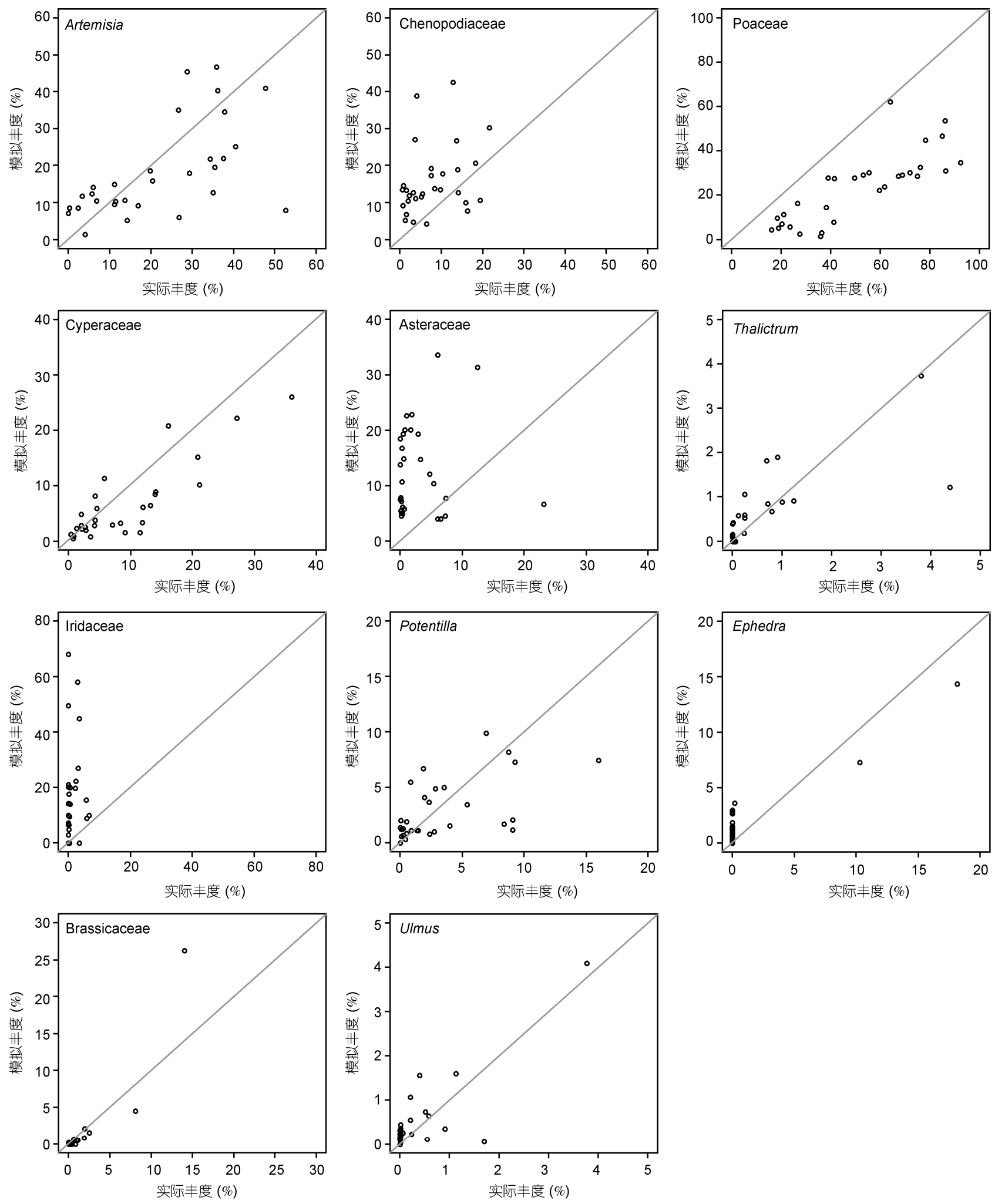

图 6 各样点主要植物类型实际丰度与利用 REVEALS 模型定量模拟植被丰度的对比 


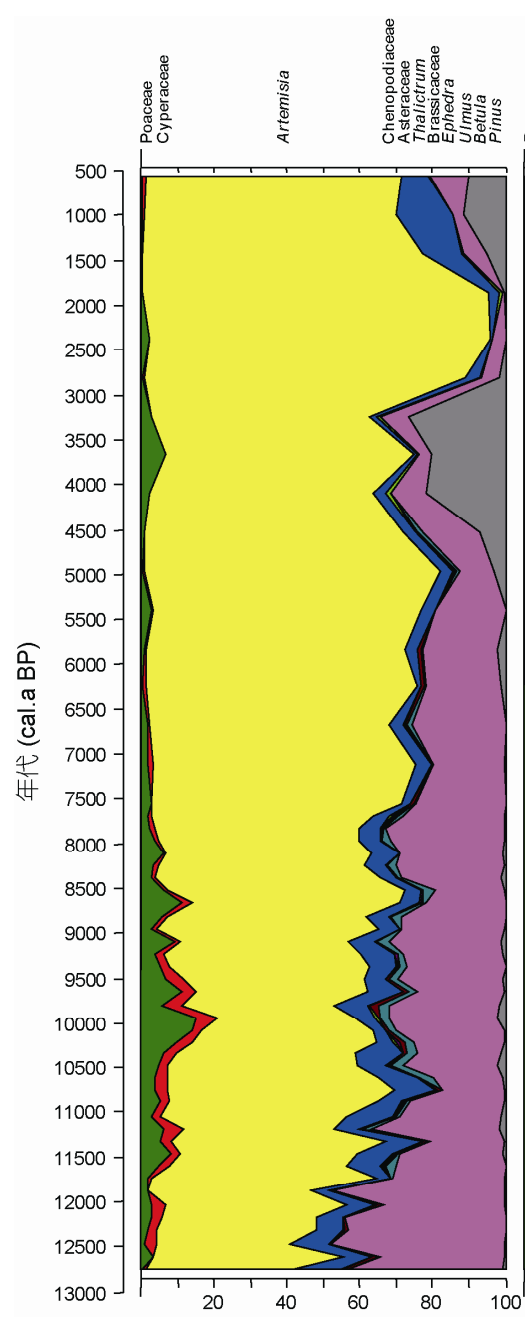

(a)
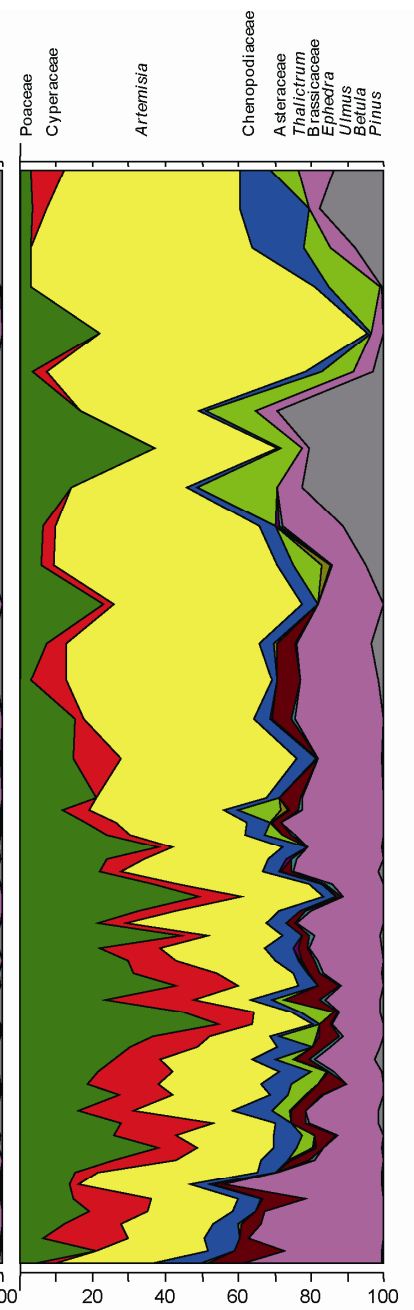

(b)

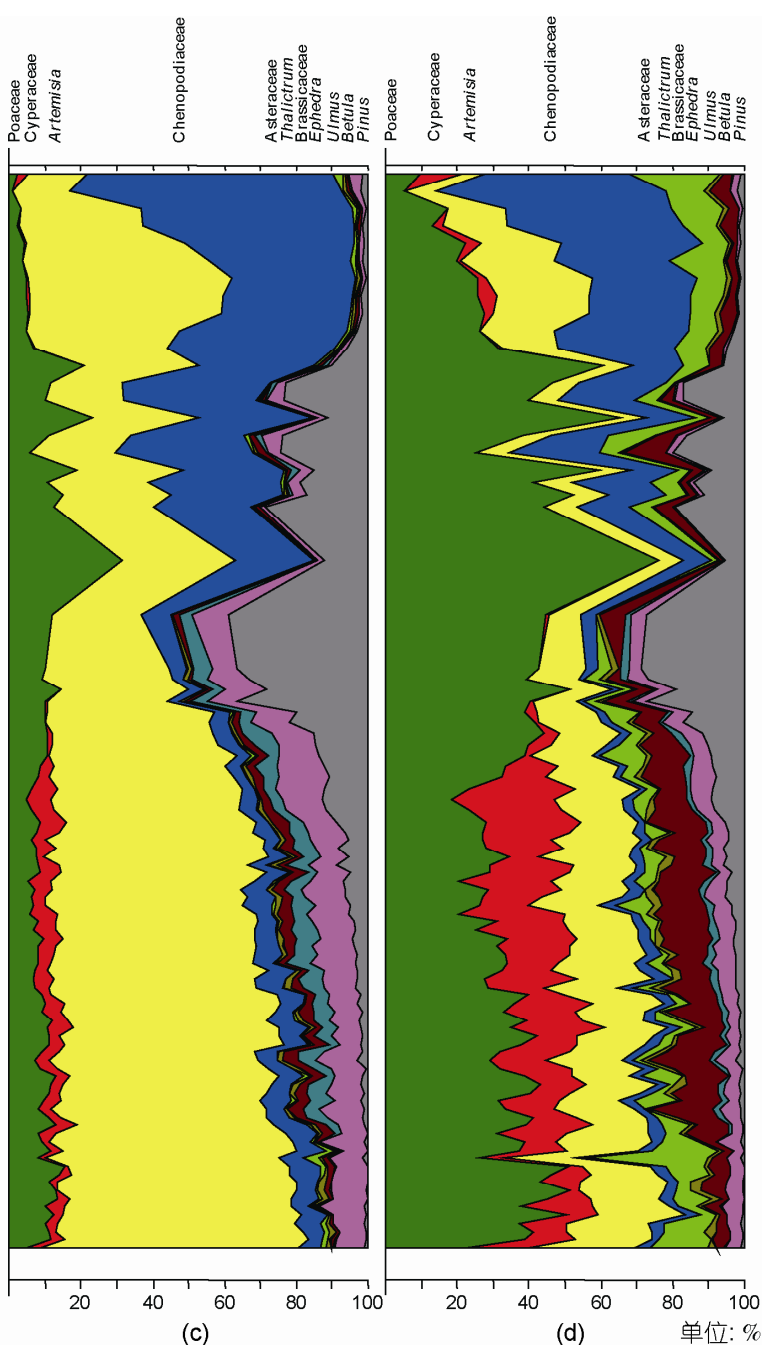

(c)

(d)

图 7 花粉百分比与重建植物丰度对比

(a) 好鲁库湖花粉百分比; (b) 好鲁库湖植物丰度; (c) 巴彦查干湖花粉百分比; (d) 巴彦查干湖植物丰度

\section{4 讨论}

通常认为, 沉积盆地越大, 相对花粉源越大 (Prentice, 1985). Sugita 估算了森林内表土及湖泊的 相对花粉源, 认为半径小于 $2 \mathrm{~m}$ 的林间空地的相对花 粉源约 50 100 m, 半径小于 $50 \mathrm{~m}$ 的小型湖泊相对花 粉源约为 300 400 m, 半径小于 $250 \mathrm{~m}$ 的中型湖泊相 对花粉源在 600 800 m 之间(Sugita, 1993, 1994). 他 还根据沉降速率将花粉分为重花粉 (沉降速率大于 $0.087 \mathrm{~m} \mathrm{~s}^{-1}$ )、较重花粉 (大于 $0.038 \mathrm{~m} \mathrm{~s}^{-1}$ )、较轻花粉 (大于 $0.025 \mathrm{~m} \mathrm{~s}^{-1}$ ) 和轻花粉 (小于 $0.025 \mathrm{~m} \mathrm{~s}^{-1}$ ), 并认为 花粉沉降速率越低, 风力传播能力越强, 相对花粉来
源范围越大(Sugita, 1993). 本研究的 11 种花粉均属 于轻花粉, 因此, 本研究将沉积盆地半径设为 $0.5 \mathrm{~m}$, 约 $1000 \mathrm{~m}$ 的相对花粉源是合理的. 同时, 本研究为 进一步验证将相对花粉源设为 $1000 \mathrm{~m}$ 的合理性, 将 模型中的风速设为研究区极大风速 $\left(29 \mathrm{~m} \mathrm{~s}^{-1}\right)$, 重新 运行模型所得到的结果仍然指示相对花粉源位于距 采样点约 $1000 \mathrm{~m}$ 附近, 也验证了风速对相对花粉源 的影响不大, 与前人结论一致(Wang 等, 2011).

通过对比 30 个样点的模拟植被丰度和实际植被 丰度, 本研究估算的多数花粉类型的相对花粉产量 是可信的; 禾本科、愁科和麻黄属相对花粉产量被高 估或低估，利用其定量重建时应谨慎; 由于菊科和鸼 
尾科在孢粉组合中出现频率和含量低, 其相对花粉 产量被显著低估. 为此, 我们认为估算相对花粉产量 时, 应选择在花粉组合和植物群落中出现频率和丰 度均较高的花粉类型, 否则估算结果不可信.

现代花粉与植被关系研究普遍认为蒿属和黎科 花粉对植物具有超代表性(Liu 等, 1999; 李月丛等, 2005; 许清海等, 2007; Xu 等, 2009), 造成超代表性 的原因往往被认为是这两类植物具有较高的花粉产 量(许英勤等, 1996; 李月丛等, 2008; 郑卓等, 2008). 中国北方典型草原区以及中国北方荒漠半荒漠地区 (Li 等, 2011)和青藏高原东部(Wang 等, 2011)相对花 粉产量估算结果均证实了前人的推断 (许英勤等, 1996; 李月丛等, 2008; 郑卓等, 2008). 青藏高原东 部相对花粉产量研究发现, 蒿属植物花粉产量是禾 本科的 2 3 倍(Wang 等, 2011), 远低于本研究的中国 北方典型草原区(11 12 倍), 可能是由于中国北方地 区较多的降雨量和较高的气温更适于蒿属植物生长, 进而产生更多的蒿属植物花粉. 中国北方典型草原 区蒿属植物的花粉产量高于藜科植物, 与荒漠和半 荒漠地区结果较一致( $\mathrm{Li}$ 等, 2011), 而青藏高原东部 蒿属植物花粉产量约是䔝科植物的一半(Wang 等, 2011), 表明相对于黎科植物, 蒿属植物更为喜暖.

禾本科花粉通常被认为对植物具低代表性(Liu 等, 1999; 李月丛等, 2005; 许清海等, 2007; Xu 等, 2009), 除花粉产量低外, 禾本科花粉保存能力较差 也可能是其重要原因(曹现勇等, 2007). Li 等(2011)发 现禾本科植物花粉产量在荒漠和半荒漠地区只有蒿 属植物的几十分之一, 甚至百分之一, 远低于本研究 结果(约十分之一), 可能是荒漠和半荒漠区气候干旱, 不利于禾本科植物生长, 同时强烈的氧化环境也不 利于禾本科花粉保存(曹现勇等, 2009). 在欧洲北部 (Broström 等, 2004; Sugita 等, 1999)和青藏高原东部 (Wang 等, 2011)莎草科植物具有和禾本科相当或略 低的花粉生产能力, 与本文研究结果一致. 欧洲花粉 产量研究发现菊科植物的花粉产量较低, 通常低于 禾本科植物(Broström 等, 2004, 2008), 也与本研究结 果一致. 中国北方草原区现代花粉研究表明, 唐松草 属花粉只在少数样品出现, 且含量低(许清海等, 2007; $\mathrm{Xu}$ 等, 2009), 而本研究估算的唐松草属花粉产量较 高, 可能与其花粉较轻, 受背景花粉影响较大有关. Broström 等(2008)总结了欧洲相对花粉产量研究成果,
发现瑞典南部榆属相对花粉产量只有 0.8 , 远低于本 研究的 12.41 和 11.53 , 可能是由于本研究区域榆属 植物盖度太低所致. 此外, 本研究估算的十字花科相 对花粉产量较高, 也可能与其植物盖度低有关.

中国北方草原区现代花粉组合中常出现含量较 低的乔木植物花粉(主要有松属、桦属等), 应由风力 长距离搬运而来(Xu 等, 2009). 现代花粉与植被关系 研究表明: 百分比大于 $30 \%$ 的松属花粉指示有松属 植物出现; 大于 $10 \%$ 的桦属花粉指示有桦属植物的 出现(许清海等, 2007), 而大于 30\%的桦属花粉表明 出现以桦属植物为主的林地(许清海等, 2007; Liu 等, 1999). 本研究中, 采样点周围均为以禾本科、蒿属和 僽科等植物为主的草原植被, 乔木植物只有榆属零 星散布, 因此现代表土花粉组合中出现的一些乔木 植物花粉, 如: 松属(小于 $14 \%$ )、桦属(小于 5\%)、鹅 耳枥属(小于 $2 \%$ )和栋属(小于 $2 \%$ ), 应由风力从研究 区东部和南部的大兴安岭山地和燕山山脉传播而来. 巴彦查干湖岩芯孢粉谱中松属和桦属花粉均低于 $30 \%$ 和 $10 \%$, 应主要来源于位于湖泊南部约 $50 \mathrm{~km}$ 外 的冀北山地, 其含量变化主要反映冀北山地植被的 变化, 而湖泊周围植被为以禾本科、蒿属、愁科、菊 科和莎草科等植物类型为主的草原植被. 花粉产量 校正后的植被盖度表明，巴彦查干湖区 $6500 \mathrm{cal}$. a BP 之前是以禾本科、莎草科、蒿属植物为主的草甸 草原, 之后由于气候变干, 演变成典型草原.

好鲁库湖岩芯中的松属花粉均低于 $10 \%$, 早、中 全新世样品中的桦属花粉含量在 $30 \%$ 上下(最大值为 46\%), 因此, 好鲁库湖周围在早、中全新世应有华属 植物分布, 而晚全新世桦属花粉含量的降低, 表明湖 泊周围植被向干草原方向发展, 此外钻孔花粉组合 中低于 $10 \%$ 的桦属花粉应来源于东部约 $60 \mathrm{~km}$ 或更 远的山地. 由于孢粉谱中出现了约 $30 \%$ 的桦属花粉, 刘鸿雁认为 $9300 \mathrm{cal}$. a BP 前好鲁库湖地区位于森林 草甸-森林草原的过渡区域, 此后一直处于森林草原 亚带, 仅在 $700 \mathrm{cal}$. a BP 前后进入草原带(刘鸿雁, 2002). 我们认为, 孢粉谱中的桦属花粉受地带性花 粉影响较大, 且依据花粉产量校正(桦属花粉产量借 鉴前人研究结果(Broström 等, 2008))后, 桦属的植被 盖度多在 $20 \%$ 以下, 因此 $5600 \mathrm{cal}$. a BP之前, 好鲁库 湖地区是以禾本科、莎草科、蒿属植物为主的草甸草 原, 伴生有桦属灌丛或疏林; 之后气候变干, 环境恶 化, 演变成现在的典型草原景观. 


\section{5 结论}

(1) 中国北方典型草原区现代花粉以草本植物 花粉(蒿属、藜科、禾本科、莎草科和菊科等)为主, 与 草原群落特征基本一致.

（2）中国北方典型草原区蒿属、藜科、禾本科、 莎草科、菊科、唐松草属、委陵菜属、十字花科、尃 尾科、麻黄属和榆属属轻型花粉, 风力传播能力强, 如沉积地点半径为 $0.5 \mathrm{~m}$, 其相对花粉源半径约为 $1000 \mathrm{~m}$, 且基本不受风速影响.
（3）榆属、蒿属、藜科、十字花科植物相对花粉 产量最高, 唐松草属植物花粉产量较高, 而菊科和㫭尾 科植物花粉产量较低, 禾本科、莎草科、委陵菜属和麻 黄属植物花粉产量适中. 其中, 菊科和感尾科相对花粉 产量被显著低估，禾本科、藜科、麻黄属相对花粉产 量被高估或低估，利用其定量重建古植被时应谨慎.

（4）依据花粉产量定量重建的植被演替表明，现 在的中国北方典型草原区 6500 5600 cal. a BP之前为 以禾本科、莎草科、蒿属植物为主的草甸草原, 之后 逐渐演变为现在的典型草原.

\section{参考文献}

曹现勇, 田芳, 许清海, 等. 2007. 阴山山脉东段花粉通量及其与表土花粉比较研究. 古生物学报, 46: 411-419

曹现勇, 田芳, 许清海, 等. 2009. 氧化环境对油松花粉保存影响试验研究. 冰川冻土, 31: 571-575

侯学显, 主编. 2001. 中国植被图集(1:100 万). 北京: 科学出版社

李刚. 2006. 浑善达克沙地稀树疏林草地生态系统研究: 生物量、生产力与生态恢复途径. 博士学位论文. 北京: 中国科学院研究生院 李素英, 李晓兵, 莺歌, 等. 2007. 基于植被指数的典型草原区生物量模型一一以蒙古锡林浩特市为例. 植物生态学报, 31:23-31

李月从, 许清海, 曹现勇, 等. 2008. 太白山北坡花粉通量与表土花粉研究. 地理研究, 27: 536-546

李月丛, 许清海, 阳小兰, 等. 2005. 中国草原区主要群落类型花粉组合特征. 生态学报, 25: 555-564

刘鸿雁. 2002. 第四纪生态学与全球变化. 北京: 科学出版社

牛建明. 2000. 内蒙古主要植被类型与气候因子关系的研究. 应用生态学报, 11: 47-52

任国玉. 1999. 科尔沁沙地东南缘近 3000 年来植被演化与人类活动. 地理科学, 19: 42-48

王永利, 云文丽, 梁存柱, 等. 2007. 内蒙古典型草原区植被格局变化及退化导因探讨. 干旱区资源与环境, 21: 144-149

许清海, 李月丛, 李育, 等. 2006. 现代花粉过程与第四纪环境研究若干问题讨论. 自然科学进展, 16: 647-656

许英勤, 阎顺, 贾宝全, 等. 1996. 天山南坡表土狍粉分析及其与植被的数量关系. 干旱区地理, 19: 24-30

羊向东, 王苏民, 薛滨, 等. 1995. 晚更新世以来呼伦湖地区孢粉植物群发展与环境变迁. 古生物学报, 34: 647-656

许清海, 李月丛，阳小兰，等. 2007. 中国北方几种主要花粉类型与植被定量关系. 中国科学 D 辑: 地球科学, 37: 192-205

郑卓, 黄康有, 许清海, 等. 2008. 中国表土花粉与建群植物地理分布的气候指示性对比. 中国科学 D 辑: 地球科学, 38: 701-714

Andersen S. 1970. The relative pollen productivity and pollen representation of north European trees, and correction factors for tree pollen spectra. Dan Geol Unders II Rskke, 96: 1-96

Broström A, Nielsen A B, Gaillard M J, et al. 2008. Pollen productive estimates of key European plant taxa for quantitative reconstruction of vegetation: A review. Veget Hist Archaeobot, 17: 461-478

Broström A, Sugita S, Gaillard M J. 2004. Pollen productivity estimates for the reconstruction of past vegetation cover in the cultural landscape of southern Sweden. Holocene, 14: 368-381

Bunting M J, Armitage R, Binney H A, et al. 2005a. Estimates of 'relative pollen productivity' and 'relevant source area of pollen' for major tree taxa in two Norfolk (UK) woodlands. Holocene, 15: 459-465

Bunting M J, Middleton R. 2005b. Modelling pollen dispersal and deposition using HUMPOL software: Simulating wind roses and irregular lakes. Rev Palaeobot Palynology, 134: 185-196

Cao X Y, Xu Q H, Jing Z, et al. 2010. Holocene climate change and human impacts implied from the pollen records in Anyang, central China. Quatern Int, 227: 3-9

Feagri K, Iversen J. 1989. Textbook of Pollen Analysis. 3rd ed. Oxford: Blackwell

Gregory P H. 1973. The Microbiology of the Atmosphere. 2nd ed. Aylesbury: Leonard Hill

Hättestrand M, Jensen C, Hallsdóttir M. et al. 2008. Modern pollen accumulation rates at the north-western fringe of the European boreal forest. Rev Palaeobot Palynology, 151: 90-109 
Hicks S. 2001. The use of annual arboreal pollen deposition values for delimiting tree-lines in the landscape and exploring models of pollen dispersal. Rev Palaeobot Palynology, 117: 1-29

Jiang W Y, Guo Z T, Sun X J, et al. 2006. Reconstruction of climate and vegetation changes of Lake Bayanchagan (Inner Mongolia): Holocene variability of the East Asian monsoon. Quat Res, 65: 411-420

Li Y C, Bunting M J, Xu Q H, et al. 2011. Pollen-vegetation-climate relationships in some desert and desert-steppe communities in northern China. Holocene, 21: 997-1010

Liu H Y, Cui H T, Pott R, et al. 1999. The surface pollen of the woodland-steppe ecotone in southeastern Inner Mongolia, China. Rev Palaeobot Palynology, 105: 237-250

Parsons R W, Prentice I C. 1981. Statistical approaches to R-values and the pollen-vegetation relationship. Rev Palaeobot Palynology, 32: $127-152$

Prentice I C. 1985. Pollen representation, source area, and basin size: Toward a unified theory of pollen analysis. Quat Res, 23: 76-86

Räsänen S, Suutari H, Nielsen A B. 2007. A step further towards quantitative reconstruction of past vegetation in Fennoscandian boreal forests: Pollen productivity estimates for six dominant taxa. Rev Palaeobot Palynology, 146: 208-220

Schofield J E, Edwards K J, McMullen J A. 2007. Modern pollen-vegetation relationships in subarctic southern Greenland and the interpretation of fossil pollen data from the Norse landnam. J Biogeogr, 34: 473-488

Soepboer W, Sugita S, Lotter A F, et al. 2007. Pollen productivity estimates for quantitative reconstruction of vegetation cover on the Swiss Plateau. Holocene, 17: 65-77

Sugita S, Gaillard M J, Brostrom A. 1999. Landscape openness and pollen records: A simulation approach. Holocene, 9: 409-421

Sugita S. 1993. A model of pollen source area for an entire lake surface. Quat Res, 39: 239-244

Sugita S. 1994. Pollen representation of vegetation in Quaternary sediments: Theory and method in patchy vegetation. J Ecol, 82: 881-897

Sugita S. 2007a. Theory of quantitative reconstruction of vegetation. I: Pollen from large sites REVEALS regional vegetation. Holocene, 17: 229-241

Sugita S. 2007b. Theory of quantitative reconstruction of vegetation. II: All you need is LOVE. Holocene, 17: 243-257

Wang H Y, Liu H Y, Cui H T, et al. 2001. Terminal Pleistocene/Holocene palaeoenvironmental changes revealed by mineral-magnetism measurements of lake sediments for Dali Nor area, southeastern Inner Mongolia Plateau, China. Paleogeogr Paleoclimatol Paleoecol, 170: $115-132$

Wang Y B, Herzschuh U. 2011. Reassessment of Holocene vegetation change on the upper Tibetan Plateau using the pollen-based REVEALS model. Rev Palaeobot Palynology, 168: 31-41

Xiao J L, Xu Q H, Nakamura T, et al. 2004. Holocene vegetation variation in the Daihai Lake region of north-central China: A direct indication of the Asian monsoon climatic history. Quat Sci Rev, 23: 1669-1679

Xu Q H, Li Y C, Tian F, et al. 2009. Pollen assemblages of tauber traps and surface soil samples in steppe areas of China and their relationships with vegetation and climate. Rev Palaeobot Palynology, 153: 86-101 